\title{
Leaf Spot Diseases of Strawberry ${ }^{1}$
}

\author{
Juliana S. Baggio, James C. Mertely, and Natalia A. Peres
}

Several different fungi and one bacterium cause leaf spot diseases of strawberry. Symptoms caused by these pathogens are often similar, leading to confusion and misdiagnosis of the disease. This publication focuses on helping growers, crop consultants, and Extension agents with the diagnosis and identification of the most common strawberry leaf spot diseases found in Florida. Generally, most of these leaf spots have not been of significant concern in the strawberry industry and are considered of minor importance. Losses associated with most of these diseases are rarely observed. Therefore, except for powdery mildew and angular leaf spot, no specific control measures and recommendations have been developed for these diseases. Research to develop specific recommendations for Pestalotia leaf spot is currently underway. Table 1 and Figure 1 below summarize the common strawberry leaf spot diseases covered in this publication.
Table 1. Common strawberry leaf spot diseases in Florida and their causal agents.

\begin{tabular}{|c|c|}
\hline Disease & Scientific name of the pathogen* \\
\hline $\begin{array}{l}\text { Pestalotia Leaf Spot and } \\
\text { Fruit Rot }\end{array}$ & Neopestalotiopsis spp. \\
\hline Common Leaf Spot & $\begin{array}{l}\text { Ramularia tulasnei (Mycosphaerella } \\
\text { fragariae) }\end{array}$ \\
\hline Leaf Scorch & $\begin{array}{l}\text { Marssonina fragariae (Diplocarpon } \\
\text { earliana) }\end{array}$ \\
\hline $\begin{array}{l}\text { Phomopsis Leaf Blight } \\
\text { and Soft Rot }\end{array}$ & Phomopsis obscurans \\
\hline $\begin{array}{l}\text { Leaf Blotch and Stem- } \\
\text { End Rot }\end{array}$ & Zythia fragariae (Gnomonia comari) \\
\hline Cercospora Leaf Spot & Cercorspora fragariae \\
\hline Target Spot & Corynespora cassiicola \\
\hline Powdery Mildew & Podosphaera aphanis \\
\hline Angular Leaf Spot & Xanthomonas fragariae \\
\hline \multicolumn{2}{|c|}{$\begin{array}{l}\text { *Fungal pathogens may have asexual and sexual reproductive } \\
\text { stages, which are given different names. The asexual stage is } \\
\text { typically the most common and is named first in the table above. } \\
\text { The sexual stage (when known) is named second and appears in } \\
\text { parentheses. By convention, scientific names in bold font are used } \\
\text { to identify the pathogen in scientific literature. These rules do not } \\
\text { apply to bacterial pathogens such as } X \text {. fragariae. }\end{array}$} \\
\hline
\end{tabular}

1. This document is PP359, one of a series of the Plant Pathology Department, UF/IFAS Extension. Original publication date November 2020. Visit the EDIS website at https://edis.ifas.ufl.edu for the currently supported version of this publication.

2. Juliana S. Baggio, postdoctoral associate; James C. Mertely, biological scientist IV; and Natalia A. Peres, professor, Plant Pathology Department, UF/IFAS Gulf Coast Research and Education Center, Balm, FL 33598.

The use of trade names in this publication is solely for the purpose of providing specific information. UF/IFAS does not guarantee or warranty the products named, and references to them in this publication do not signify our approval to the exclusion of other products of suitable composition. Use pesticides safely. Read and follow directions on the manufacturer's label.

The Institute of Food and Agricultural Sciences (IFAS) is an Equal Opportunity Institution authorized to provide research, educational information and other services

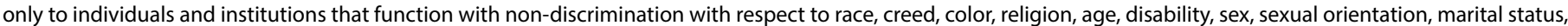

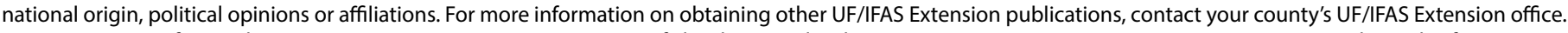
U.S. Department of Agriculture, UF/IFAS Extension Service, University of Florida, IFAS, Florida A \& M University Cooperative Extension Program, and Boards of County Commissioners Cooperating. Nick T. Place, dean for UF/IFAS Extension. 


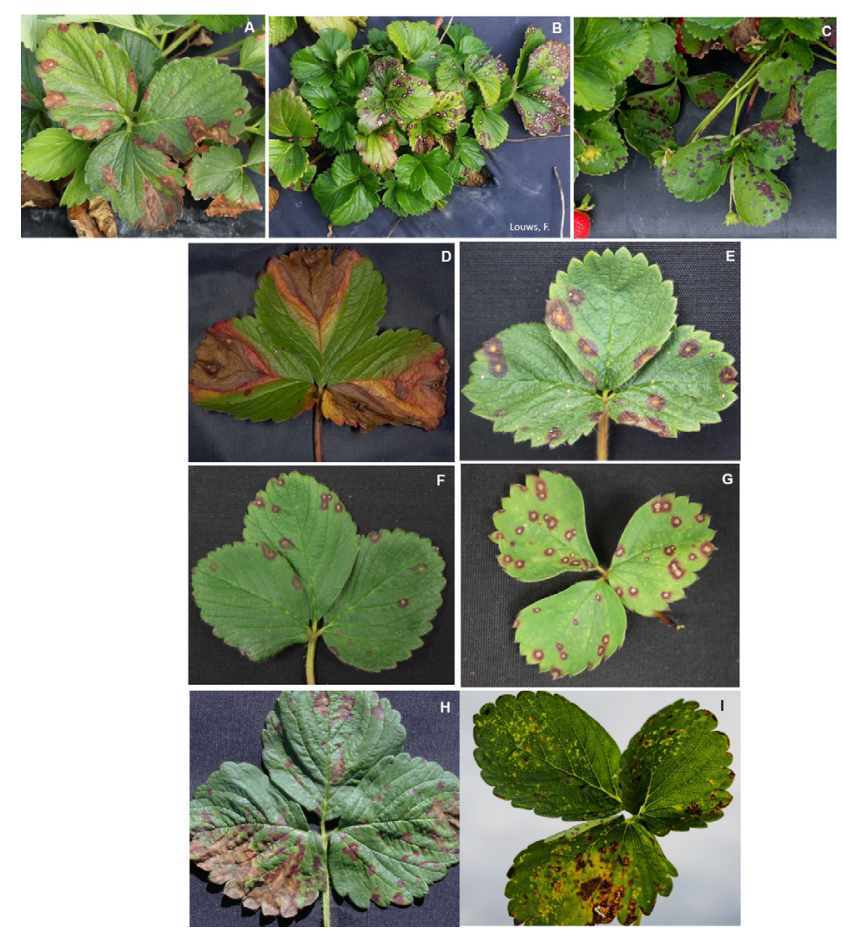

Figure 1. Typical symptoms of A) Pestalotia leaf spot, B) common leaf spot, C) leaf scorch, D) Phomopsis leaf blight, E) leaf blotch, F) Cercospora leaf spot, G) target spot, H) powdery mildew, and I) angular leaf spot on strawberry leaves.

Credits: A, C-I: UF/IFAS GCREC; B: F. Louws

\section{Pestalotia Leaf Spot and Fruit Rot}

Pestalotia leaf spot and fruit rot are caused by species of Neopestalotiopsis. Symptoms are characterized by light-todark-brown spots of varying sizes, irregularly distributed on infected leaves (Figure 2A). Young spots are often circular but become irregular as they enlarge, especially near the margins of the leaf. In advanced stages, the spots increase in size and may merge. Pestalotia leaf spots can be confused with early stages of leaf blotch (caused by Gnomonia comari), which is also covered in this publication, but are distinguished by black spore masses that form in the tan centers of older spots, especially under humid conditions (Figure 2B).

In recent outbreaks in Florida, severe spotting often produced blight-like browning of older leaves, eventually killing them. The disease can also decline plant vigor, resulting in stunted growth and development of smaller and weaker leaves. In severe cases, the pathogen infects roots and crowns, leading to the eventual death of the plant.

Fruit symptoms can be confused with anthracnose fruit rot (AFR). Like AFR, fruit rot begins as dry, light-tan, slightly sunken, irregularly shaped lesions $2-4 \mathrm{~mm}$ in diameter. The lesions expand and may take over the entire fruit. Unlike AFR, however, large lesions are eventually covered by dark fruiting bodies (acervuli), which produce spores in shiny black droplets of liquid (Figure 2C). These symptoms take time to develop in the field but may be hastened by incubating diseased fruit (or leaves) in moist plastic bags for 24 to 48 hours to induce sporulation.

The fungus produces spores on the surface of infected tissues, which can be spread by water and farm operations. Disease development is favored by consecutive or extended rain events and temperatures above $50^{\circ} \mathrm{F}\left(10^{\circ} \mathrm{C}\right)$, with optimum temperatures between $77^{\circ} \mathrm{F}$ and $86^{\circ} \mathrm{F}\left(25^{\circ} \mathrm{C}\right.$ and $30^{\circ} \mathrm{C}$ ). When these conditions are prolonged, epidemics develop, which are very difficult to control.

For more information and specific recommendations, visit https://edis.ifas.ufl.edu/pp357.

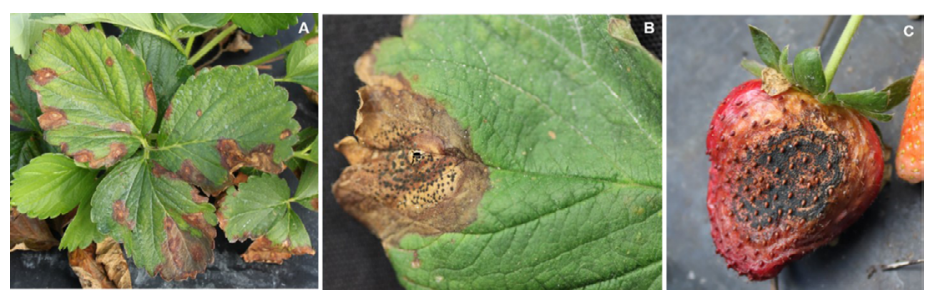

Figure 2. Pestalotia leaf spot and fruit rot symptoms caused by Neopestalotiopsis spp.: A) leaves with light-to-dark-brown spots; B) black structures (spores) of the fungus in older necrotic tissue; and C) fruit covered by black spores of the pathogen.

Credits: UF/IFAS GCREC

\section{Common Leaf Spot}

Common leaf spot, caused by Mycosphaerella fragariae, is also known as Mycosphaerella leaf spot, Ramularia leaf spot, "rust," bird's-eye spot, "gray spotness," or white spot. Symptoms can be confused with early stages of leaf blight (caused by Phomopsis obscurans) and leaf blotch (caused by Gnomonia comari), although the lesions caused by this pathogen do not enlarge as aggressively. It can also be confused with leaf scorch (caused by Diplocarpon earliana), which is covered in the next section.

Symptoms are characterized by leaves with small and circular leaf spots with light to tan centers and purplish borders (Figure 3). Lesions usually start on the upper leaf surface as small, deep purple, round to irregularly shaped necrotic spots, which can grow to $1-2 \mathrm{~mm}$ in diameter. On young leaves, spots remain light brown, whereas on older leaves the center changes from tan or brown to gray or white, and the necrotic center is surrounded by reddish-purple to rusty-brown borders. Lesions occur less frequently on the underside of the leaves, and the color is not as vivid. Intense spotting may lead to death of the infected leaves.

Symptoms differ based on the strawberry cultivar, strain of the fungus, and temperature range. Uniformly rusty-brown spots without purplish borders or light necrotic centers 
may be produced on young leaves when warm and humid conditions are present.

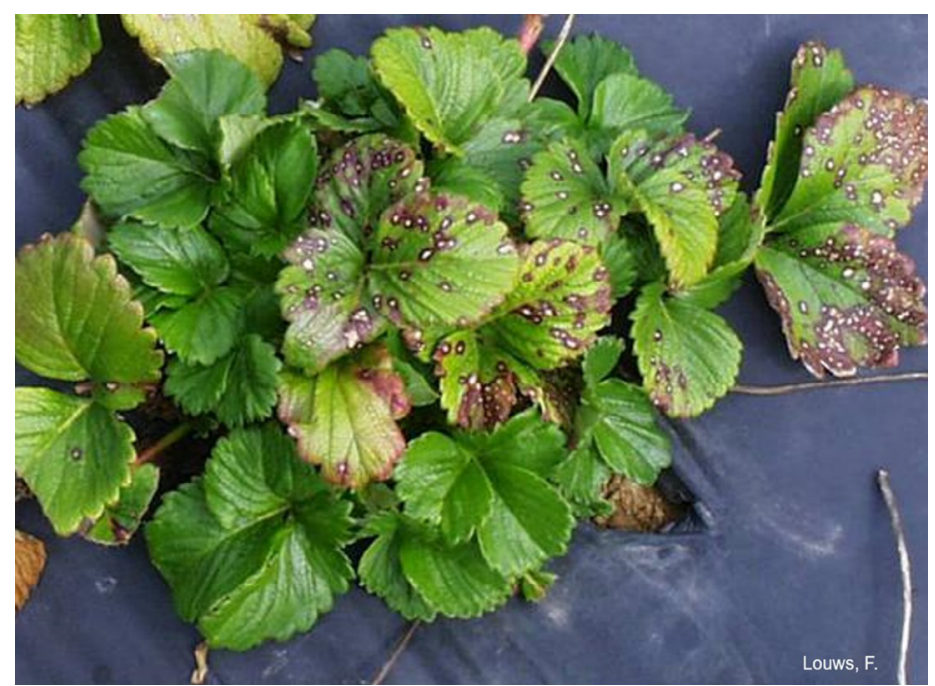

Figure 3. Common leaf spot symptoms caused by Mycosphaerella fragariae: leaves with light to tan centers and purplish to dark margins on the upper leaf surface.

Credits: F. Louws

M. fragariae also causes spots on fruit, calyxes, petioles, and runners. Under high humidity, superficial black spots $(1 / 4$ inch across) can be formed on fruit around groups of seeds. Fruit spots and black seeds are usually limited to one or two per fruit.

In Florida, the asexual stage (Ramularia tulasnei) is more common and produces conidia that can be dispersed by splashing water from rains or overhead irrigation. The pathogen is favored by high humidity and temperatures between $50^{\circ} \mathrm{F}$ and $80^{\circ} \mathrm{F}\left(10^{\circ} \mathrm{C}\right.$ and $\left.27^{\circ} \mathrm{C}\right)$.

\section{Leaf Scorch}

Leaf scorch is caused by the fungus Diplocarpon earliana. Symptoms can be mistaken for common leaf spot, caused by $M$. fragariae.

Several small, irregular, and purplish to tan spots or "blotches" (1-5 $\mathrm{mm}$ in diameter) develop on the upper surface of leaves (Figure 4A). In contrast to common leaf spot (caused by $M$. fragariae), the centers of the blotches remain purple or slowly develop small brownish centers. When blotches are numerous and start to merge, tissues between the lesions often turn bright red to brown (Figure $4 \mathrm{~B})$. In severe cases, entire leaves curl up at the margins, turn brown, and acquire a burned (scorched) appearance.

D. earliana also infects petioles, flowers, and fruit. Infected sepals and petioles develop irregular purple to brown spots (Figure 4C). Badly spotted sepals may turn brown, resulting in "dead caps", which make fruit unattractive and lower the market grade. In severe cases, infected flowers and fruit may die.

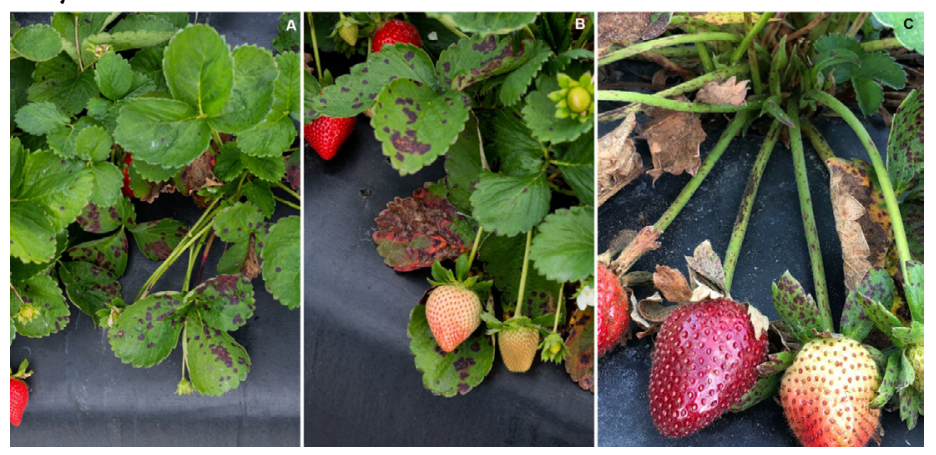

Figure 4. Leaf scorch symptoms caused by Diplocarpon earliana: A) several small, irregular, and purplish blotches on the upper surface of leaves; B) coalescence of blotches and purplish to bright red tissues between the lesions; and C) symptoms on leaves, petioles, and sepals (dead calyxes) and less attractive fruit.

Credits: UF/IFAS GCREC

Leaf scorch is favored by long periods of leaf wetness, frequent rain, and temperatures between $60^{\circ} \mathrm{F}$ and $77^{\circ} \mathrm{F}$ $\left(15^{\circ} \mathrm{C}\right.$ and $\left.25^{\circ} \mathrm{C}\right)$. Older and middle-aged leaves are infected more easily than young ones. Disease occurrence is common when fungicides labeled for strawberry production are not applied regularly. Applications of captan and other strawberry fungicides seem to be effective in reducing disease incidence.

\section{Phomopsis Leaf Blight and Soft Rot}

Phomopsis leaf blight and soft rot is caused by the fungus Phomopsis obscurans. Symptoms start as one to numerous circular reddish-purple lesions on a leaflet. During the early stages, symptoms are practically indistinguishable from common leaf spot lesions, caused by $M$. fragariae, due to the development of gray centers in the spots. As the disease progresses, spots enlarge to $\mathrm{V}$-shaped lesions with light-brown centers and darker-brown outer zones. Lesions follow major veins progressing inward (Figure 5A). The fungus produces black fruiting bodies (pycnidia) on the inner zone of the lesion. If pycnidia are not present, leaves may be incubated in a moist chamber for 24 to 48 hours to induce sporulation.

The fungus also infects petioles, runners, calyxes, and fruit. Pink and red fruit are usually affected, and initial symptoms are characterized by round, light-pink, and water-soaked lesions. In more advanced stages, lesions turn light brown at their margins and darker brown and crusty toward the centers, covered with several black pycnidia (Figure 5B). 
The pathogen is usually introduced with transplants, and the disease might build up in fruit production fields, but it is rarely a concern among growers. The disease is favored by humid weather, and the pathogen is dispersed by water splash from rains or overhead irrigation.
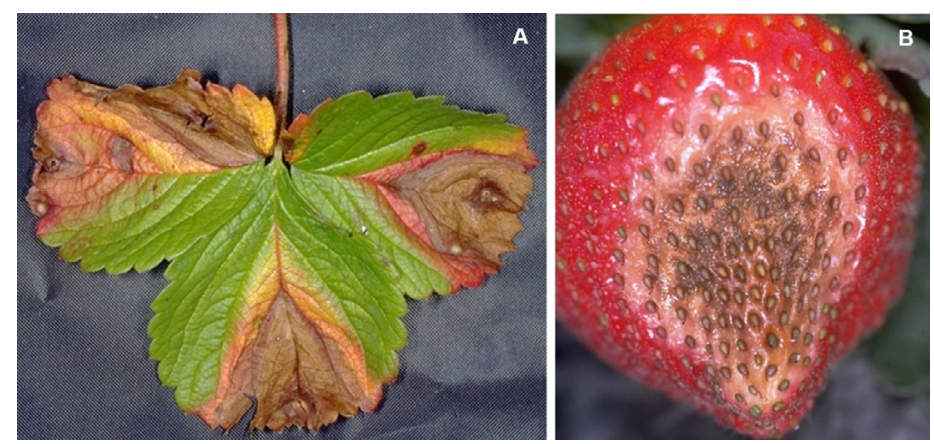

Figure 5. Phomopsis leaf blight and soft rot symptoms caused by Phomopsis obscurans: A) leaf with V-shaped lesions with light-brown centers and darker-brown outer zones; and B) fruit lesions covered with black pycnidia of the pathogen.

Credits: UF/IFAS GCREC

\section{Leaf Blotch and Stem-End Rot}

Leaf blotch, caused by Gnomonia comari, may be confused with several other leaf spot diseases, especially when lesions are young. Young spots are brownish and roughly circular with purple borders (Figure 6A). The spots expand aggressively over time, often forming large light brown necrotic areas. Such areas may develop faint zonate patterns and often extend to the margins of the leaf (Figure 6B). Fruiting bodies (pycnidia) form on old spots as upraised tan to brown structures whose color resembles surrounding tissues. As a result, they may not be readily visible. If pycnidia are not visible with a hand lens, leaves may be incubated in a moist chamber for 24 to 48 hours to induce sporulation. Old outer leaves often die from a combination of leaf spotting and infection of the lower petioles.

The pathogen also infects flowers, calyxes, and fruit, causing stem-end rot (Figure 6C). Irregular brown areas form on green fruit, causing them to ripen prematurely or dry up, inhibiting further development. Symptoms on older fruit are characterized by irregular brown lesions, generally expanding from under the cap. Soft rot symptoms are produced on ripe fruit, which can be covered with dark fruiting bodies (Figure 6D).

Leaf blotch and stem-end rot occur sporadically and are often associated with the nursery source of the transplants. Disease development is favored by overhead irrigation and frequent rain. Currently grown cultivars such as Florida127 $\left(\right.$ Sensation $\left.^{\mathrm{TM}}\right)$ and Florida Brilliance seem particularly prone to the leaf spot phase of this disease. G. comeri is considered a weak pathogen and usually infects plants through wounds and stomata on the leaves.

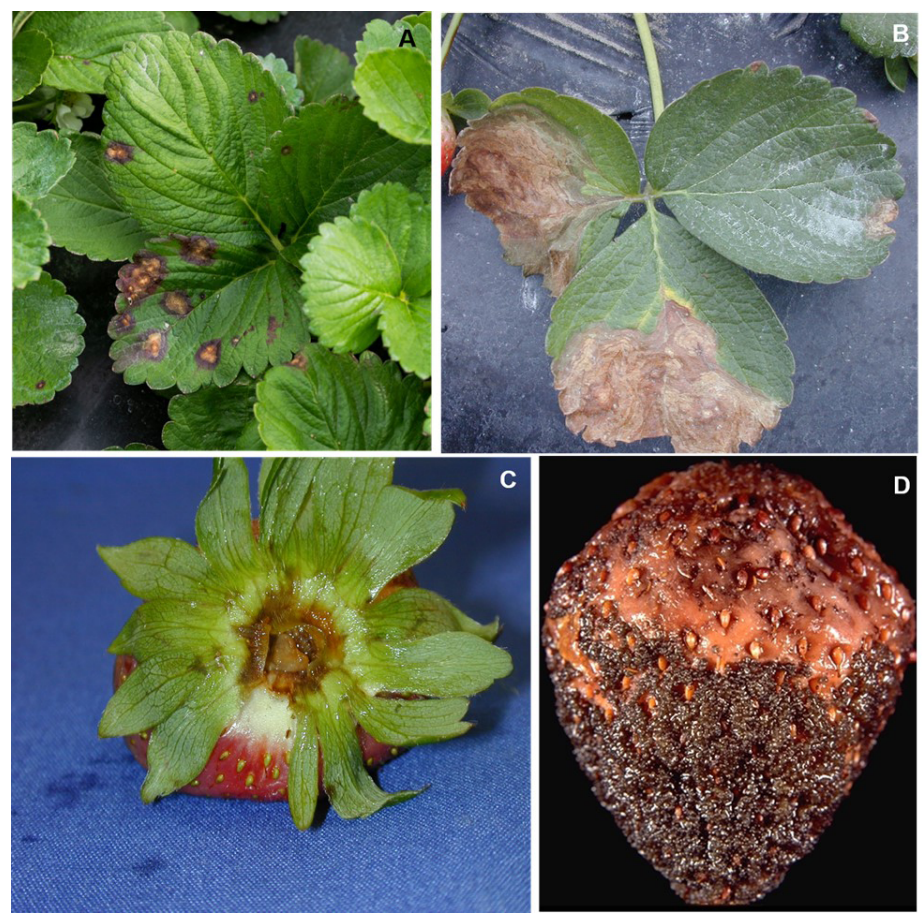

Figure 6. Leaf blotch and stem-end rot caused by the fungus Gnomonia comari: A) brownish lesions with a purplish outer zone on young leaves; B) light-brown necrotic blotches on older leaves; C) stem-end rot symptoms on the calyx; and D) soft rot symptoms on ripe fruit covered with dark fruiting bodies.

Credits: UF/IFAS GCREC

\section{Cercospora Leaf Spot}

Cercospora leaf spot is caused by the fungus Cercospora fragariae. In the early stages, leaf spots are small, circular, and uniformly purplish/reddish with very light-colored (almost white) centers, apparent only on the upper surface (Figure 7A). The spots resemble common leaf spot (caused by $M$. fragariae) but are smaller with lighter centers and more irregular shapes.

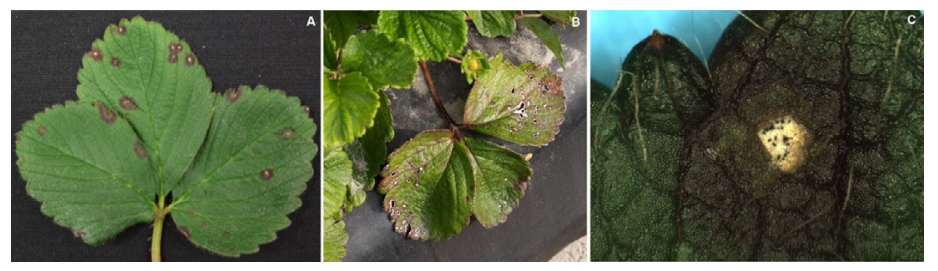

Figure 7. Cercospora leaf spot caused by the fungus Cercospora fragariae: A) small, circular purplish/reddish spots with light-colored centers; B) late-stage symptoms where the center of the spots become necrotic and fall out; and C) white centers of the spots covered with black stromata of the fungus.

Credits: UF/IFAS GCREC

In advanced stages, the necrotic centers become brittle and may fall out, resulting in "shot hole" symptoms (Figure 7B). The spots remain relatively small and irregular with a more defined dark-purple outer zone, and they occasionally coalesce. On the lower leaf surface, the spots are bluish to tan 
in color and appear more diffuse. Spore production occurs on the upper surface of the leaf, in the white centers which become dotted with small dark stroma or knots of fungal cells (Figure 7C). Like many fungal pathogens, C. fragariae is spread by water splash. However, it does not infect the fruit and is considered a minor strawberry pathogen.

\section{Target Spot}

Target spot is caused by the fungus Corynespora cassiicola. Early symptoms are characterized by small ( 3 to $5 \mathrm{~mm}$ across), circular to irregular spots on leaves with dark brown borders and beige centers (Figure 8A). When spotting is intense, leaf lesions can expand to $20 \mathrm{~mm}$, and surrounding leaf tissues may become yellow (Figure 8B). In severe infections, spots can occupy half of the leaf area (Figure 8C). Symptoms can also be observed on petioles and the fruit calyx (Figure 8D).
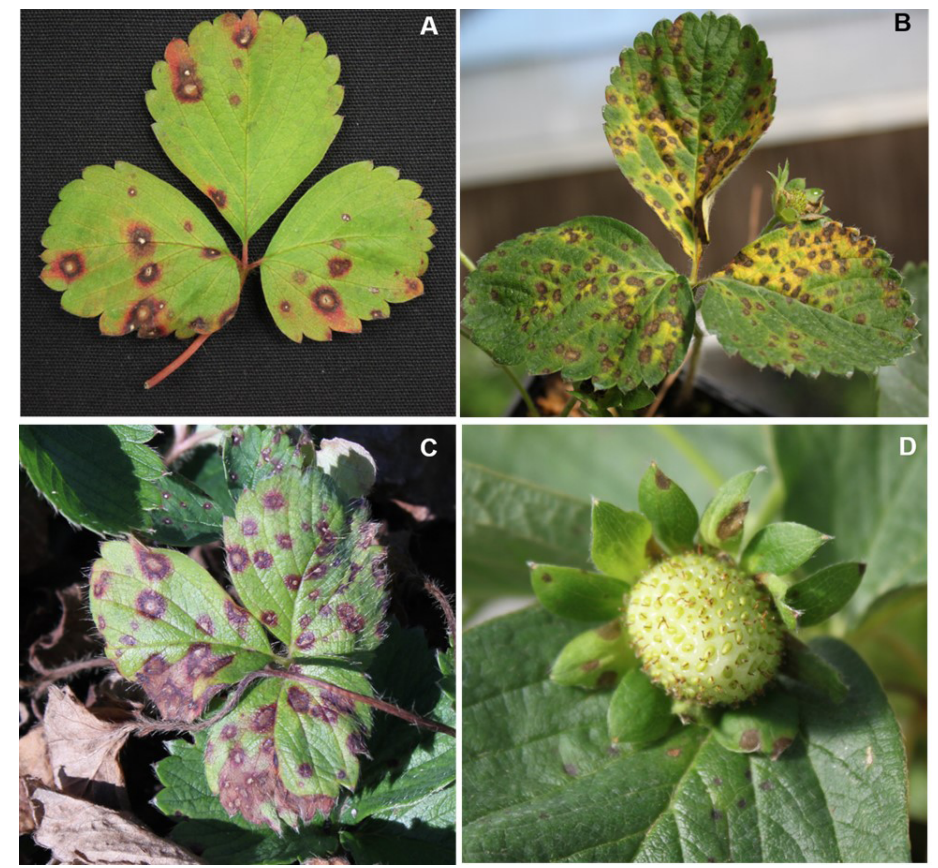

Figure 8. Target spot caused by the fungus Corynespora cassiicola: A) circular to irregular spots on leaves with dark-brown borders and beige centers; B) dense spotting with associated yellowing; C) spots occupying half of leaf area in severe infection; and D) pale-brown spots on fruit cap (calyx).

Credits: UF/IFAS GCREC

This disease has been reported recently on strawberry and seemed associated with nursery transplants that were infected by another host in close-by fields.

\section{Powdery Mildew}

Strawberry powdery mildew is caused by the fungus Podosphaera aphanis. The disease is easily recognized by the appearance of fuzzy white fungal growth on lower leaf surfaces (Figure 9A). Small black fruiting bodies (cleistothecia) may develop on the undersides of heavily infected leaves (Figure 9B). Leaf cupping is common and occurs when the margins of diseased leaves curl upward and inward (Figure 9C). In some cultivars, irregular red or purple/brown patches develop on one or both leaf surfaces (Figure 9D), which can be confused with other leaf spot diseases. Mycelial growth also occurs on flowers and fruit, especially those embedded in the plant canopy, as well as on the upper leaf surface of plants growing in tunnels and greenhouses.

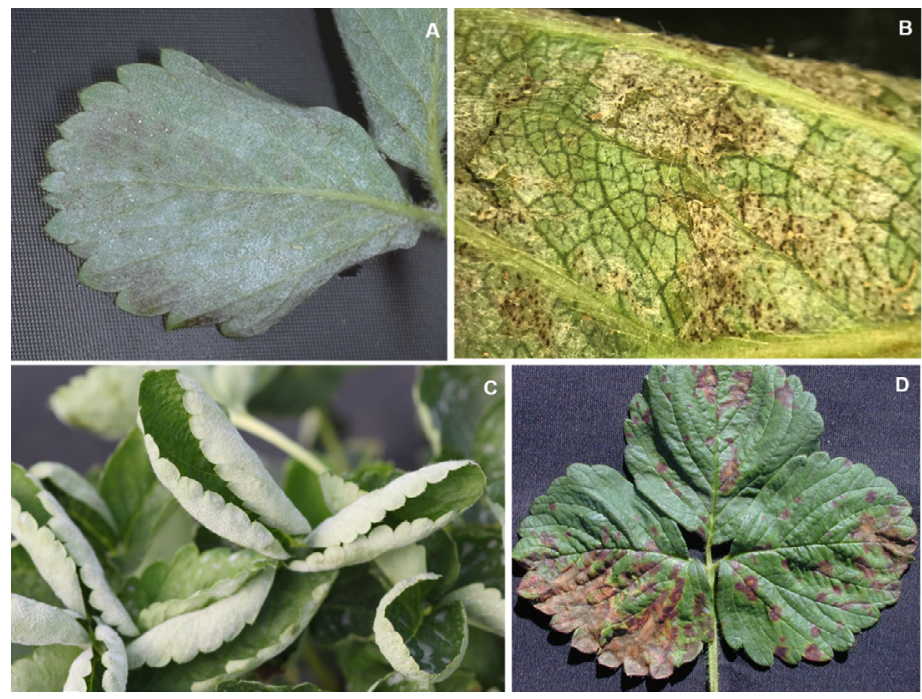

Figure 9. Powdery mildew caused by the fungus Podosphaera aphanis: A) fungal growth on lower leaf surfaces; B) small black fruiting bodies (cleistothecia) on the undersides of infected leaves; C) leaf cupping and curled margins of diseased leaves; and D) irregular red or purple/ brown patches on infected leaves of some cultivars.

Credits: UF/IFAS GCREC

P. aphanis is carried on infected transplants, and it is not believed to persist over our hot, wet Florida summers. Spore germination and fungal growth are favored by mild temperatures between $60^{\circ} \mathrm{F}$ and $77^{\circ} \mathrm{F}\left(15^{\circ} \mathrm{C}\right.$ and $\left.25^{\circ} \mathrm{C}\right)$, high relative humidities ( $75 \%$ to $98 \%$ ), and rapid vegetative growth, which may explain why epidemics often occur between November and January. High temperatures, strong sunlight, heavy rains, and wet leaf surfaces suppress disease development. Powdery mildew is readily controlled by various fungicides applied at 2-week intervals, but applications must be started early in the season (late November), before fungal growth is extensive and leaf curling becomes obvious.

For more information and specific management recommendations, visit https://edis.ifas.ufl.edu/pp129. 


\section{Angular Leaf Spot}

Angular leaf spot (ALS) is a bacterial disease caused by Xanthomonas fragariae. Leaves are the primary target tissue, although leaflike sepals on the fruit caps, known as fruit calyx, may also be infected. Mass spotting is common during outbreaks in Florida, resulting in yellowing, blighting, and premature death of older leaves (Figure $10 \mathrm{~A})$. Spots are small in size (3-5 $\mathrm{mm}$ across) and confined by leaf veins, giving them a blocky or angular shape.

Young spots look water-soaked (Figure 10B) but appear translucent when held up to the light (Figure 10C). This "windowpane" effect is diagnostic for ALS. Individual spots may also coalesce and run together along the larger veins of a leaf. Older spots turn brown to black with age. When environmental conditions are favorable, sepals are also infected. In severe cases, mass spotting of the sepals results in "brown cap" symptoms, rendering the fruit unmarketable (Figure 10D).

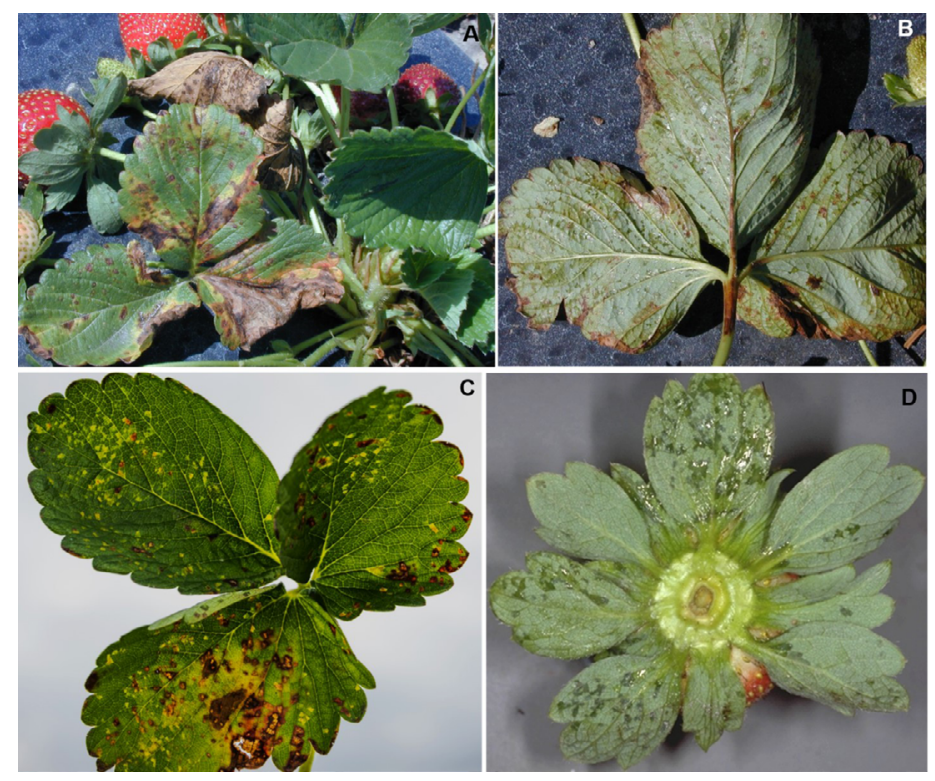

Figure 10. Angular leaf spot caused by the bacteria Xanthomonas fragariae: A) yellowing, blighting, and premature death of older leaves; B) water-soaked lesions on the lower side of leaves; C) translucent spots, producing the "windowpane" effect on the leaves; and D) mass spotting of the sepals resulting in "brown cap" symptoms on the calyx. Credits: UF/IFAS GCREC

ALS outbreaks are common in some seasons but not others. Epidemics usually occur when rains or overhead irrigation for frost protection are frequent. During wet, humid weather, bacteria ooze from the spots on the lower leaf surface and are spread by splashing water, farm equipment, and harvesters. ALS is not controlled by fungicides but is suppressed by copper-containing products, as well as the plant defense promoter Actigard. Unfortunately, these products also tend to suppress yield when applied too frequently or at high rates.
For more information and specific management recommendations, visit https://edis.ifas.ufl.edu/pp120.

\section{References}

Ellis, M. A. 2016. Strawberry Leaf Diseases. Ohioline. PLPATH-FRU-35. The Ohio State University Extension. Plant Pathology. https://ohioline.osu.edu/factsheet/ plpath-fru-35

Louws, F., G. Ridge, and B. Cline. 2019a. Gnomonia Leaf Blotch and Stem-End Rot of Strawberry. NC State Extension Publications. https://content.ces.ncsu.edu/ gnomonia-comari-leaf-blotch-of-strawberry

Louws, F., G. Ridge, and B. Cline. 2019b.

Phomopsis Leaf Blight of Strawberry. NC State

Extension Publications. https://content.ces.ncsu.edu/ phomopsis-leaf-blight-of-strawberry\#

Maas, J. L. 1998. Compendium of Strawberry Diseases, 2nd edition. St. Paul: APS Press.

Onofre, R. B., C. S. Rebello, J. C. Mertely, and N. A. Peres. 2019. "First Report of Target Spot Caused by Corynespora cassiicola on Strawberry in North America." Plant Dis. 103:1412. 